\title{
Causes of Grade Nine Students' Grade Retention in General Secondary Schools of Dabat Woreda in North Gondar, Ethiopia
}

\author{
Nahom Eyasu \\ Department of Sociology, College of Social Sciences and Languages, Mekelle University, Ethiopia \\ E-mail: tenseye@gmail.com
}

Received: 07-11-2016

Accepted: 29-04-2017

Published: 30-04-2017

doi:10.7575/aiac.ijels.v.5n.2p.84

URL: http://dx.doi.org/10.7575/aiac.ijels.v.5n.2p.84

\begin{abstract}
One of the great problems of Ethiopia for the educational arena is retention. Averagely $8.07 \%$ of each year of the secondary education students is repeated due to lack of achievement in this country. The percentage of retention in a country shows what proportion of students is regularly repeated in the same grade and who are, therefore, committing different crimes and misbehaved behaviors. Grade retention predicts many negative student outcomes: the frustration and humiliation associated with repeating the curriculum, combined with one's physical size, may result in an increase in aggression and oppositional behavior. The main purpose of this study was to investigate some of the causes that contribute to grade nine students' grade retention in general secondary schools of Dabat district. It has attempted to identify the major factors under two headings: in-school and out-of-school factors to present separate area of intervention. In order to attain the objectives, the study was carried out in two general secondary schools which were selected using comprehensive sampling techniques. The study involved $264(\mathrm{M}=106 \& \mathrm{~F}=158)$ grade repeaters and 44 teachers and 2 principals. The data gathered were analyzed using percentage, mean, Spearmen rank order correlation coefficient and t-test. Based on the result of the analysis, among the in-school factors, the highest percentages were observed for difficulty of language of instruction, students' failure to study hard, poor quality of teaching, lack of guidance and counseling and frequent absenteeism of students were in-school related. On the other hand, low level of family income, parent (pupils) health problem, lack of parents support and child labor were identified as the major outof-school causes for grade retention in grade nine secondary schools. It was also found out that the combined effect of both in-school and out-of-school factors was important in explaining students' grade retentions in the secondary schools of the district. The incidence of the problem is relatively higher among girls than among boys.
\end{abstract}

Keywords: In-school Causes; Out-of-school Causes; Grade nine; Retention; Secondary school students, Ethiopia

\section{Introduction}

The high school completion, especially for grade 12 are viewed as individuals who have achieved important goals and, therefore, ready to take on new challenges such as job training, colleges, career, marriages, family, home, financial obligations and other adult responsibilities (Brodbelt, 1987). The young high school graduates, especially in the developing countries like Ethiopia are required to make up the chronic shortages of middle-level technical and material cadres (Tilaye, 1999). They disseminate the knowledge necessary to improve agricultural techniques, health services, governmental policy reforms and other changes to the common people (Tilaye, 1999). In short, they can serve an important change agents sustained economic growth of the nation (Genet, 1998). However, when students are evaluated there is variation in their level of achievement some might be success and other may not be success and failure is determine by evaluation (Genet, 1998). Arends (1994) indicated that evaluation helps to understand how well a particular student, group of students or teachers have performed on asset of learning objectives. Regarding to this idea, the National Association School Psychologists (2003) indicated that in most developing countries at national, state and district level developing grade level promotion standards. These standards underlined that students are promoted from one grade to the next based on the academic performance; this was one of the case in Ethiopia (Arends, 1994).

Studies have shown the factors that relate to students educational wastage in different regions and countries (Genet, 1998; Mayer, Mullens and Moore, 2000; Tesfay \& Thehay, 2006; Tilaye 1997). These factors can be categorized in a number of ways (Tilaye, 1997). Some of these factors are related to institutional practices and others are associated with society's customs, beliefs and attitudes about education. Many writers also claim that school environment is one of the determinant factors for grade retention of students: the availability of instructional materials and facilities, teachers' education and attitude, class size, academic difficulty etc (Bustillo, 1993; Fuller, 1987). Other than raising the amount of time required to complete the educational cycle and demand for incurring additional resources, grade repetition or failure reduces the intake capacity of the school (UNESCO, 1980). It also results in overcrowded classes (Brimer \& Pauli, 1971). Consequently, the students' and their parents' motive and interest towards bringing good working environment on teaching-learning process decrease retention away (Davison, 1993; Eisemon, 1997; Hussen, 2000; 
Levy, 1971). Levy (1971) revealed that a one percent increase in the average repetition rate is associated with an almost one percent increase in the commutative dropout rate, which means the average repetition rate can determine to the dropout rate. Thus, grade repetition is found to be the main causes of an internal inefficiency (Haddad, 1979).

On that account, most effective short run means of improving the internal inefficiency of education appears to be the reduction of grade retention, a measure which has been suggested as urgent priority in earlier studies of educational wastage (Hussen, 2000). In fact, policy measures to reduce grade retention cannot be successfully designed unless reasons for such repetitions are known (Elsemon, 1997).

Hence, the causes of grade nine grade retention is needed in order to minimize the problem because over the past century, a primary question in psychological and sociological research has been how the parents, peers, teachers, the social environment influence the occurrences of high retention rate of secondary school in Ethiopia (UNESCO, 2014).

\subsection{Statements of the problem}

In Ethiopia, the gross enrollment rate in primary education is $87 \%$ for both girls and boys combined; this decreases to $38 \%$ in lower secondary, with a student transition rate to secondary school of $93 \%$ (World Bank, 2014). In this country, the primary net enrollment rate is $68 \%$ and the primary completion rate is $47 \%$. Both of these indicators provide making towards universal primary education (World Bank, 2014). Despite progress, Ethiopia's education indicators are still poor and below Sub-Saharan averages (UNESCO, 2014). Ethiopia is ranked $126^{\text {th }}$ out of 127 countries in the Education for All (EFA) development index (UNESCO, 2014).

One of the great problems of this country for the educational arena is retention (UNESCO, 2014). Averagely 8.07\% of each year of the secondary education students is repeated due to lack of achievement in Ethiopia (World Bank, 2014). The percentage of retention in a country shows what proportion of students is regularly repeated in the same grade and who are, therefore, committing in different crimes and misbehaved behaviors (Nailing and Sheila, 2009).

In Dabat district, 282 grade nine students were encountered to repetition in 2013 among 2,231 students, which means $12.6 \%$ of the total students of grade nine in 2013; this empirical evidence shows that the retention rate at this district is more than the national retention rate of $8.07 \%$ (Dabat district education Bureau, 2014). This retention rate has been increasing in grade nine that affects the psychosocial domain, peers and social relationships of the children (McCoy \& Reynolds, 1999). Besides to that, more than 100 research studies in the last century show that grade retention predicts many negative student outcomes: the frustration and humiliation associated with repeating the curriculum, combined with one's physical size, may result in an increase in aggression and oppositional behavior (Pagani et al., 2001). Students who are struggling academically do not automatically catch up to their peers if retained without targeted intervention (Nailing and Sheila, 2009).

Retention is associated with negative outcomes in all academic area as well as in social and emotional adjustment like peer relationships, self-esteem, and problem behaviors, cigarette use, alcohol and drug abuse, early onset of sexual activity, suicidal intention, and violent behaviors (Anderson et al., 2005 ; Blair, 2002; Jimerson et al., 2000). Other scholars like Jimerson (1999) stated that retention is one of the most powerful predictors of later high school dropout, retained students are $20-50 \%$ more likely dropout of high school than non-retained students.

Relative to students who are promoted, retained students are more likely to be female, minority such as children, disabled person, younger than their peers (McCoy and Reynolds, 1999). In Dabat and Woken secondary schools 53.5\% and $62.7 \%$ of the total repeaters are females respectively; this is due to low socioeconomic status, and living in poor households and single parent families (Blair, 2002). They are also more likely to have poorer academic performance prior to retention; significantly lower social skills and poorer emotional adjustment; more problem behaviors, such as inattention and absenteeism; more school transfers; poorer health; and disabilities (Anderson et al., 2005; Pagani et al., 2001). Parents of retained students are more likely to have lower IQ scores and lower levels of cognitive functioning, lower educational levels, lower occupational levels, less commitment to parenting responsibilities for their children's education, lower expectations of their children's educational attainment, and less involvement in school (Pagani et al., 2001).

While the problem of grade retention in secondary schools have been occurring in Dabat District, lack of well documented to show the existed causes of such problem in this district are too much insufficient, which means the causes of grade nine students' grade retention in Dabat district have remained largely on documented and there is a dearth of research and information on which to base counter- activities. Due to the fact that some researchers explained like Fasil (1990) on the Implementing Education Policies in Ethiopia towards retention and Jessica Lopez and Maoulidi on the cost of grade retention have not widely used probability and non-probability random sampling techniques in studying about the largest amount of repeaters number in Ethiopia; The uses of quantitative and qualitative sample size of their studies have less significant in drafting policies and minimizing the problem of repetition in secondary schools; and the ways of checking the reliability and the validity of their studies for the implementing the educational policy in Ethiopia as well as reducing as much as possible tackling the retention problems secondary education in Ethiopia were less significant. They are less likely to investigate the causes of grade nine students' grade retention in Ethiopia in the general and the Dabat and Woken secondary school in particular.

Therefore, this research has tried to fill such gaps for investigating of the causes of grade nine students' grade retention in general secondary schools of Dabat district in North Gondar. 
The general objective of this study is to investigate of the causes of grade nine students' grade retention in general secondary schools of Dabat district in North Gondar. The main specific objectives of this study were:

1. To examine in-school factors for grade nine students' grade retention in the study area

2. To describe the out-of-school factors for grade nine students' grade retention in the study area

3. To compare the reasons given by the students and teachers for the retention of grade nine Dabat district general secondary schools grade repeaters

4. To investigate the contribution of gender to the retention of grade nine Dabat district general secondary schools grade repeaters

\section{Literature Review}

\subsection{Meaning and Nature of Grade Retention}

Society invests in education with intent of obtaining returns, with minimum inputs, as it does in other sectors (Haddad, 1979). Failure to use the available resources efficiently indicates wastage (UNESCO, 1980; Haddad, 1979; Brimer \& Paul, 1971). Wastage in education, therefore, shows the ability to attain the intended goals that have been set due to various obstacles in educational system UNESCO (1988). Levy (1971) note different obstacles that make the realization of the educational aim difficulty, among which is grade retention.

Grade retention is referred to retaining students in the same grade previously attended or level of study where the normal expectation is either to promote or complete the course (Elsemon, 1997; Jimerson, Anderson \& Whipple, 2002). Brimer and Paul (1971) also define retention as "students who is a given year, remain in the same grade and doing the same work as in the previous year". More specifically, Potter (1996) defines failure as "retaining students in grade previously attended for a year or more due to (in most case) his/her unsatisfactory academic performance." In this case, as Haddad (1979) states academic failure could not be the only reason for grade failure; as students who leave schools to work in the harvest or because of illness, are also considered as failure when they return the following years to the same grade. Thus, the repeaters are the students who are detained in the same grade for a year or more due to different reasons to satisfy grade requirement for promotion to the next higher grade.

\subsection{Pattern of Grade Retention in Secondary Schools}

Most writers agree that grade retention is a more series problem in the developing countries. For instance, Carron and Chau (1996) testify that the educational system of most developing countries is characterized by high repetition rate and that hampered the normal progress of students in education. Thomas (1975) also ascribes that grade retention has been a common problem in the developing countries which "retards" the educational progress of most of the students. Particularly, grade nine serves a bottle neck for many students who began their academic years only to find their academic skills are insufficient for high school level work. Various researcher identified specific risk factors, such as low attendance or lack of student engagements, which identify future grade retention (Alliance for Excellent Education, 2009).

As a developing country, Ethiopia could not escape from the problem of grade retention. The retention rates of Ethiopia, in grade 9-10, have oscillated up and down in the 20 to 25 percent range for most the period (World Bank, 2002). The 1995/96 data shows that the rate of repetition in high school was 17.9 percent (MOE, 2000). Again, in Amhara Regional state the data obtained from Amhara Educational Bureau, department of the statistics reveal that the average percentage of repeaters in high school was 15.7 percentages in 1998/99 academic year. This seems to be adequate evidence to conclude that grade retention has significant problem in secondary schools and requires great attention in the country in general and in Amhara in particular.

\subsection{Factors Related to Students' Grade Retention in Secondary School}

In order to identify the factors affecting grade retention of students, studies have been undertaken in different areas. These studies shows that the major causes can be broadly categorized under two headings, as in-school and out-ofschool related factors. For instance, Rose et al. (1997) and Elsemon (1971) thoroughly summarized various causes of repetition and dropout under internal and external factors. Thus, since grade retention said to be the result of the interaction of both school related (internal) and out-of-school (external) factors, a separated discussion on them would help to give a clear view of the problem in secondary schools.

\subsubsection{Internal Factors (School Factors) for Grade Retention in Secondary schools}

As different researchers have mentioned it, school environment is one of the major factors that contribute students' grade retention (Malglad, 1994; Hyde 1989 Rose et al., 1997; Setu, 2002; World Bank, 1998). The main internal factors or in-school factors have tried to put here:

\subsubsection{Large Class Size}

It is possible to well acquaint with twenty or thirty students in class discussion, but the number exceeds, it becomes more difficult for teaching and learning in any subject. According to the proposition of the Ministry of Education (2002), "the overall standard classroom ratio in Ethiopian secondary school is 1:50." However, the size of the students 
body per class is influenced by the size and number of existing rooms, the nature of the subject matter, the number of the existing teachers and students, the method of teaching to be employed, etc.

In line to this, Anderson (1969) asserted that "because of large number of students, teaching more probably tends to lecture method, rather using different methods according to the nature of the subject." Large classes reduce the teachers' sense of freedom in choosing teaching methods; it is possible to teach a large number of students in a classroom.

\subsubsection{Students Absenteeism}

Similarly, Haddad (1979) reveals that frequent absenteeism from school (14 days to 2 months) is highly associated with repetition of classes and dropout. A recent study made by Elsemon (1997) on repetition has also confirmed that absenteeism has been significantly related to grade retention. In addition to this, a study of village -based schools in Malawi found that students with higher rate of attendance had greater learning gains and lower rates of repetition (Miske et al., 1988). In Ethiopia, Research also report that absenteeism in higher for girls than that of boys (Rose et al., 1997; Yelfign et al., 1995; UNESCO-UNICEF, 1988).

\subsubsection{Guidance and Counseling Services}

Most students in secondary schools are in the age range of 15 to 21 (UNESCO, 1888; Hamblin, 1883). Psychologists called this period "adolescence age" or Juvenile age" as a highly complex transitional period from child hood to maturity. During adolescence period students manifest broader and more sophisticated interests, many personal, social and emotional problems which a rises from home, boy-girl problems, difficulties with studies etc (UNESCO, 1987). Similarly, Garman and Brown (1989) review that since adolescence, especially for the students are those who have followed in secondary school are subject to complex "life difficulties" the situation causes poor performance on the part of students.

Cooksey (1992) found that age of adolescences of as a cause for students wastage in schools. To confirm this, UNESCO (1988) has this to say secondary schools deal with students at a high complex and irresponsible age when an evolving personality is preparing for entry in to adult life. A storm process of building up the personality ensures and this will require the guidance, orientation and counseling of pupils at secondary school.

Thus, the condition calls upon trained counselors services for high school adolescence to adjust themselves to their school environment, their home, and their peers. Emphasizing this, many researches affirm that lack of guidance and counseling services particularly at secondary school can aggravate educational wastages (Tilaye, 1997; UNESCO, 1988). Ballantine (1993) also confirm that poor progress of students can be reduced or corrected by means of properly organized guidance and counseling services in secondary schools.

\subsubsection{Teachers Verbal Proficiency}

The verbal proficiency of teachers in determining student academic achievement has been strongly emphasized in relating with teacher's total effectiveness in teaching (Brophy, 1983). Brophy (1983) stated by citing Good and Biophy (1986), teacher behaviors and patterns of teacher-student interaction associated with student achievement gains in the following three major conclusions:

1. Teachers make difference. Some teachers reliably elicit greater gains than others because of differences in how the teach.

2. Differences in achievement gains occurring part because of differences in exposure to academic content and opportunity to learn.

3. Teachers who elicit greater achievement gains do not merely maximize "time on task"; in addition, they spend a great deal of time actively instructing their students.

\subsubsection{Teacher's absenteeism}

Teachers' absenteeism in teaching-learning process highly affects students' academic performance. Contents to be covered during the given academic period will be left without being covered if teachers are constantly absent from school. According to Fuller (1986), a total of 2 analysis or studies have been made regarding teachers' absenteeism and its impact on students' academic performance.

\subsubsection{Difficulty of Instructional Language}

In dealing with the importance of communication in curriculum, Jimmerson and Kaufman (2003) put that language is a large part of any professional task. They added the success of secondary school mainly depends upon the level of achievement in language. For supporting this idea, Gother cited in Marland (1980) depicted that unless the pupil can read, write and talk completely, he can't benefit from their teaching which the secondary school provides.

In Ethiopian context, many researchers have concluded that most students on secondary schools lack the Basic English language skills to help them cope with the academic requirements. Tilaye (1999) states that one factors that increased the retention rate among students in secondary school in that most of them have difficult to comprehend the subject due to language problem and they cannot follow their courses properly.

\subsubsection{External Factor (Out-of-school Factors) for grade Retention in secondary school}

While influence of external variables on school dropout is well documented, less is known about how they affect grade retention. Therefore, some of those out-of-school variables assumed to facilitate grade retention are discussed subsequently. 


\subsubsection{Socio Economic Status of Family}

The researchers, such as Stevenson et al. (1978) as cited in Good and Brophy (1983) stated that:

No single SES variables cause all of other in any simple way, but the educational level of parents is probably the most basic because the other variables lose most of their power for predicting things such as students' achievement. Once the educational level of parents is statistically controlled, in any case, parental educational level is especially important to teachers because it is linked to parental interest in and attitude towards education. (p. 83)

This indicates that parents who are well educated generally value of education is expected their children to be well educated too.

\subsubsection{Parents Educational Background}

A lot of research studies have shown that parents and the family considerable contribution to child's achievement from early childhood through high school (Merga, 1999; King and Hell, 1993). In this regard, Tylor, et al. (1983) pointed out that the educational level of parents influence children's school performance more than other family related variables such as income, family size and occupation similarly. Stevenson and Baker (1987) also indicated that the educational level predicts more of the variance in students' achievement than do other family background variables, particularly for young children. Students who come from educated parents are better able to cope up with the challenges of the learning process as they have enough orientation and preparation at home (King and Hin, 1993). There are some studies that tried to differentiate the degree of parental education influence by gender.

\subsubsection{Disintegration or Breakdown of Family}

Many researchers have argued that the structural situation of the family strongly affected the learning situations of students. AS Brimer and Pauli (1971) pointed out, the disunity of the family in different cases such as death, divorce or distance, work, and the like are the other additional factors that affect the students' grade retention in the secondary schools. These imply that the disunity of the children's family influence their strong positive feeling towards educational achievement by creating tension and instability in their life situation (UNESCO, 2000).

\subsubsection{Child Labor}

Child labor is the principal factor for grade repetition and dropout of children from schooling, children help to increase the labor power of parents both by engaging in domestic service, thus make their parents for income generating activities and by working to subsidize family income (Genet, 1998). In poor families, children contribute as much as $40 \%$ to family income; they set to school only when the labor needs of the family have been met income to ensure household labor, it has an effect on students' grade retention (Cole, 1997). As it is cited by Genet (2000) from Brown (1991) in rural areas, it is a common practice to withdraw children from school for the harvest season because all hands are need to pick up crops.

\subsubsection{Patterns of Grade retention by sex}

Studies of different times and places have come up with varying result regarding grade retention pattern by sex. A brief review of these is, therefore, essential (Elsemon, 1997). Several research reports such as Elsemon (1997) and UNESCO (1993) indicated that the tendency to repeat grades is higher among girls than boys because of girls' responsibilities at home and the gender division of labor in the house holds economy. Frequently grade retention for females is higher than of males in most African countries (Odaga and Heneveld, 1995). And similarly, Elsemon (1997) report on ten African countries that more than one female student out of three was actually repeating in general secondary school. These finding suggest the extent of the problem. Likewise, in Ethiopia, research results show that grade retention higher for girls than boys (Rose et al., 1997; and UNESO, 1993). Researches like Dereje and Derese (1997) review that the percentage of girls' class repeaters is higher in all grade education in Ethiopia too.

\subsection{Theoretical Framework of Grade Retention}

\subsubsection{Social Comparison Theory}

Social comparison theory (Festinger, 1954) offers a potentially useful theoretical framework for understanding retention. The theory posits that individuals use cues in their environment to make inferences about their own and others' relative abilities. Classrooms provide multiple cues of children's relative abilities, including teachers' differential responses to students' responses, public praise and criticism, length of time provided for children to answer a question, graded assignments, and student grouping based on ability (Brophy, 1983) To support this idea, research on the effects of grade retention has found that retained children improve in achievement relative to their younger grade mates (Anderson et al., 2005). The retained child is also likely to improve more than promoted students in the short term in meeting classroom expectations for behavioral and social competencies (Tomchin and Impara, 1992).

However, other scholars have argued against the above consensus was that with an extra year of physical maturation, the retained child's abilities to inhibit impulsive actions, to focus attention, and to conform to classroom rules are expected to improve relative to the prior year and relative to his or her (younger) classmates. In the longer term, however, the benefit of an extra year of maturation may wane (Blair, 2002), retention increases students' externalizing 
problems (Pianta et al., 1997). The enhanced social and academic performance during the repeat year will be a turning point for retained students (Tomchin and Impara 1992).

\subsubsection{Social Cognitive Theory}

It views human behavior as the product of the interactions between an individual's environmental, cognitive, and personal factors (Jimerson, 1999). Environmental conditions and a student's reaction to them have an impact on the probability that a student will or not stay in school. If a student is given the tools to cope with a disadvantaged environment - such as negative role models, relationships with the peers who careless about their academic excellence, and a negative sense of self-efficacy — might they be less likely to leave and repeat similar grades. On the other issue, grade retention has a serious long-term negative impact on a student's academic career (Jimerson, 1999; Jimerson et al. 2000; Shepard and Smith, 1990). In fact, this line of research has revealed that non retained, low-achieving students graduate at secondary school than similar retained students, with similar characteristics, such as their prior levels of academic achievement, suggesting retention has an independent negative impact on students Jimerson et al., 2000).

\subsubsection{Social Learning Theory}

This theory emphasizes the interaction between the students and environment, in a quest not so much to learn why students repeat similar grades, but rather to identify the conditions under which they might do so (Bandura, 1986). Imitation or modeling serves social-learning theory as one useful way to explain the development of certain kinds of behavior on retention (Bandura, 1997)

Bandura and Walters (1963) showed that personality traits that happened in repeaters such as aggression or dependency, attempting to suicide and other negative social aspects can be learned through watching others and seeing what kinds of rewards or punishments they receive for their actions when they repeat or promote their grades with their peers and other social environment. Responses that lead to valued outcomes (or positive reinforcement) are likely immolated. But the learning that takes place may be influenced by the situation in which it occurs or by the specificity of reinforcements, or rewards. Individuals learn to discriminate one situation from another Bandura and Walters, 1963; Bandura, 1997).

\section{Research Methods and Design}

The research design for this study is cross sectional because of the variable measures at a single time (Bernard, 2000). This study has used both qualitative and quantitative (concurrent mixed research method) because of: validation of the findings in terms of accuracy; checking for biases in research methods; compensating strengths and weakness; comprehensive explanations (Densecoble, 2007). And also, there is no rule that prohibits mixed research method (Bernard, 2000). Hence, this research method has very important in clearly describe the causes of grade nine students' grade retention in general secondary schools of Dabat district in North Gondar through triangulating the two research methods (quantitative and qualitative). More specifically, the researcher has broadly used quantitative research method, for the purposes of data and method triangulation; he has also used qualitative research method at the same time during data collection, analyze, and interpretation.

Generally, this research has been applied when it has been used quantitative and qualitative data in order to provide a comprehensive analysis of the problems. In this design, an investigator collected both forms of data at the same time during the study and then investigate the information in the interpretation of the overall results (Creswell, 2009).

\subsection{Study area}

This study was conducted in Dabat district in North Gondar, which is in Amhara Regional National State, Ethiopia. The town is located $814 \mathrm{Km}$ from the North West part of Addis Ababa, the capital city of Ethiopia.

The inhabitants of this town are totally about 145, 458 (Census, 2007). Among the total population of this town, 41,039 students attend primary and secondary schools, but, 282 children in grade nine were under retention, which means they repeated similar class at the same year. So, the researcher has focused on factors for grade nine students' grade retention by the causes of in- school and out-of-schools causes that are living in this district in the case of Dabat and Woken secondary schools.

\subsection{Target Population}

The study population was the students who have repeated grade nine at Dabat and Woken grade nine secondary schools.

3.3 Sampling Techniques

3.3.1 Quantitative Method Sampling Techniques

The researcher's quantitative method sampling techniques is probability sampling techniques because in one hand, it states as individual data are about attributes of individuals in population. Each student has an age level of exposure on retention (Edmund, 2000). The researcher has taken the whole grade nine repeaters at Dabat and Woken secondary school in the year of 2013.

The investigator of the causes of grade nine students' grade retention on this study has used cluster random sampling because Ethiopia has nine regions, such as Tigre, Afar, Amhara, Oromia, Benshangul Gumuz, Gambela, Somali, Harari, and south nation nationalities, and two city administrations such as Addis Ababa and Diredewa, each regions has also variety zones; each zone has also different woredas; and each woredas has also rural and urban residents. Dabat district 
is found in Amhara region in North Gondar zone. So, for taking the ultimate sample such as the repeaters of grade nine at Dabat district, cluster random sampling was used

\subsubsection{Qualitative Method Sampling Techniques}

This research also applied purposive or judgmental sampling technique because the researcher needed informants so as to ensure the primary and the secondary data in the selection of a few cases for intensive study, and gathering and collecting critical cases.

3.4 Sample Size

3.4.1 Quantitative Sample Size

The researcher of this paper took the whole repeaters in grade nine and the whole class room teachers at Dabat district and woken secondary schools in 2013.

Table 1. List of sample general secondary schools with corresponding number of grade repeaters in 2013 academic year

\begin{tabular}{lllll}
\hline \multirow{2}{*}{ No } & \multicolumn{1}{c}{ School } & \multicolumn{3}{c}{ No of grade repeaters in 2013 } \\
\cline { 3 - 5 } & & Male & Female & Total \\
\hline 1 & Dabat general secondary school & 80 & 92 & 172 \\
2 & Woken general secondary school & 41 & 69 & 110 \\
3 & Total & 121 & 161 & 282 \\
\hline
\end{tabular}

Source: Dabat district education office, 2014

According to the data obtained from sample schools, there were 282 grade nine students who had repeated grades in the two sample schools in 2013 academic year. During the data collection, the researcher collected the names of grade repeaters from 2013 academic year rosters and checked their names from 2014 academic year students list. However, the writer found only 264 students among those who had repeated grades in 2013 academic year and were attending their education in 2014 academic year in both sample schools.

The other 18 students were not found in the sample schools and might have dropped out or transferred to other schools. Thus, from available 264 students who had retain grade 9 in 2013 academic year and attending their education in the two sample schools in 2014 academic year. All repeaters from both sample schools totally 264 repeater were selected to fill the questionnaire

The students who have repeated grade nine were the target population of the study, the opinion of teachers of the sample schools was gathered to verify responses from different directions. Accordingly, all 44 homeroom teachers of the selected academic year were selected to take part in the study. Thus, 44 teacher respondents were used to fill the questionnaire.

This study was measured by main dependent variable called students' grade retention in general secondary school relative to their gender. On the other hand, the determinants of the grade retention (in the case of independent variables) were seen as grouping them in to two major categories: those related to the student experiences in the school (in-school related factors) and in his/her socio-economic environments (out-of-school related factors).

\subsubsection{Qualitative Sample Size}

The researcher has used only two key informants for the purpose of triangulating the quantitative data. These key informants gave to intensive data for why grade retention happened.

\subsection{Data Collection}

The researcher used both primary and secondary data to investigate the causes of grade nine students' grade retention in the study area. Primary data were collected quantitatively and qualitatively from the selected secondary schools. The qualitative data were collected from the informants that provided data on the problems of grade nine students' grade retention. The principals of both secondary schools were interviewed for this purpose. The Quantitative data consisted of 264 and 44 census survey questionnaires collected from students and teachers respectively. The questionnaire was in Amharic and English. The secondary data comprised the archives, different documents, brochures, templates, magazines, internets, monthly and annual reports related to the causes of grade nine students' grade retention in general secondary schools of Dabat district in North Gondar.

\section{Results}

\subsection{Characteristics of respondents}

As Table 2 depicts, most of the student respondents were females (59.37\%). Regarding their age, 94.42\% were at the age of 15-19. Most of them (58.16\%) reported that they were from urban areas while the rest were from rural residence. Regarding their fathers' education, $70.91 \%$ of grade repeaters reported their fathers were illiterate, $25.49 \%$ had primary education while $3.58 \%$ had secondary or higher education. With reference to their mothers' education, a majority 
$(88.84 \%)$ had illiterate mothers, $8.76 \%$ had mothers with primary education and only $2.39 \%$ had obtained secondary school and above.

Table 2. Characteristics of student respondents $(\mathrm{N}=251)$

\begin{tabular}{|c|c|c|c|}
\hline Variable & Grade nine repeaters characteristics & Frequency_(F) & $\%$ \\
\hline \multirow[t]{3}{*}{ Sex } & Male & 102 & 40.63 \\
\hline & Female & 149 & 59.37 \\
\hline & Total & 251 & 100 \\
\hline \multirow[t]{4}{*}{ Age } & 11-14 years & - & - \\
\hline & 15-19years & 237 & 94.42 \\
\hline & 20 and above & 14 & 5.58 \\
\hline & Total & 251 & 100 \\
\hline \multirow[t]{3}{*}{ Residence } & Urban & 146 & 58.16 \\
\hline & Rural & 105 & 41.84 \\
\hline & Total & 251 & 100 \\
\hline \multirow{4}{*}{$\begin{array}{l}\text { Fathers' } \\
\text { education }\end{array}$} & Illiterate & 178 & 70.91 \\
\hline & Primary school & 64 & 25.49 \\
\hline & Secondary school and above & 9 & 3.58 \\
\hline & Total & 251 & 100 \\
\hline \multirow{4}{*}{$\begin{array}{l}\text { Mothers' } \\
\text { education }\end{array}$} & Illiterate & 223 & 88.84 \\
\hline & Primary school & 22 & 8.76 \\
\hline & Secondary school and above & 6 & 2.39 \\
\hline & Total & 251 & 100 \\
\hline
\end{tabular}

Table 3. Characteristics of teacher respondents $(\mathrm{N}=41)$

\begin{tabular}{|c|c|c|c|}
\hline Variable & & $\mathrm{F}$ & $\%$ \\
\hline \multirow[t]{3}{*}{ Sex } & Male & 26 & 63.41 \\
\hline & Female & 15 & 36.59 \\
\hline & Total & 41 & 100 \\
\hline \multirow{4}{*}{$\begin{array}{l}\text { Academic } \\
\text { qualification }\end{array}$} & Diploma & 1 & 2.44 \\
\hline & Degree & 40 & 97.56 \\
\hline & MA/MED/MS & - & - \\
\hline & Total & 41 & 100 \\
\hline \multirow{6}{*}{$\begin{array}{l}\text { Years of } \\
\text { experiences }\end{array}$} & $0-5$ years & 23 & 56.09 \\
\hline & $6-10$ years & 10 & 24.39 \\
\hline & 11-15 years & 3 & 7.31 \\
\hline & $16-20$ years & 5 & 12.31 \\
\hline & Above 20 years & - & - \\
\hline & Total & 41 & 100 \\
\hline
\end{tabular}

According to the personal details shown in Table 3, the teacher respondents consisted of $63.41 \%$ male. It further shows that $56.09 \%$ of teachers have $0-5$ years of service and $24.39 \%$ of teachers have $6-10$ years of experience. Also $7.31 \%$ and $12.19 \%$ of teachers have $11-15$ and 16-20 years of experience respectively. Most (97.56\%) of the teachers were degree holders. Therefore, the male teachers who were degree holders have had higher probabilities to have 0-5 work experiences 
4.2 Reasons for Grade nine students grade retention

Grade retention is believed to be caused by various reasons that could emanate either from outside or inside the school system. In this study, an attempt was made to discuss some of the factors that lead students' grade retention of school. The impact of these factors is discussed here:

\subsubsection{In-school factors}

Table 4. In-school related factors

\begin{tabular}{|c|c|c|c|c|c|c|}
\hline \multirow[t]{2}{*}{ No. } & \multirow[t]{2}{*}{ In-school factors } & \multirow[t]{2}{*}{ Level } & \multicolumn{2}{|c|}{ Grade repeaters } & \multicolumn{2}{|c|}{ Teachers } \\
\hline & & & F & $\%$ & $\mathrm{~F}$ & $\%$ \\
\hline \multirow[t]{5}{*}{1} & Problem of Instructional language & High & 143 & 56.97 & 1 & 51.22 \\
\hline & & Average & 102 & 40.63 & 0 & 48.78 \\
\hline & & Little & 6 & 2.39 & - & - \\
\hline & & Not at all & - & - & - & - \\
\hline & & Total & 251 & 100 & 1 & 100 \\
\hline \multirow[t]{3}{*}{2} & Frequent absenteeism & High & 152 & 60.55 & 29 & 70.73 \\
\hline & & Low & 99 & 39.45 & 12 & 29.27 \\
\hline & & Total & 251 & 100 & 41 & 100 \\
\hline \multirow[t]{4}{*}{3} & Guidance and counseling service & Always & 10 & 3.92 & - & - \\
\hline & & Sometimes & 127 & 50.59 & 16 & 39.02 \\
\hline & & Not at all & 114 & 45.42 & 25 & 60.98 \\
\hline & & Total & 251 & 100 & 41 & 100 \\
\hline \multirow[t]{5}{*}{4} & Teachers verbal proficiency & High & 75 & 29.88 & 2 & 4.87 \\
\hline & & Average & 160 & 74 & 19 & 46.34 \\
\hline & & Little & 16 & 6.38 & 12 & 29.26 \\
\hline & & Not at all & - & & 8 & 19.53 \\
\hline & & Total & 251 & 100 & 41 & 100 \\
\hline \multirow[t]{5}{*}{5} & Large class size & High & - & - & - & - \\
\hline & & Average & 72 & 69 & 4 & 9.75 \\
\hline & & Little & 104 & 43 & 27 & 61.85 \\
\hline & & Not at all & 75 & 88 & 10 & 24.40 \\
\hline & & Total & 251 & 100 & 41 & 100 \\
\hline \multirow[t]{5}{*}{6} & Teachers frequently absenteeism & High & 17 & 6.77 & - & - \\
\hline & & Average & 39 & 15.53 & - & - \\
\hline & & Little & 169 & 67.33 & 31 & 75.60 \\
\hline & & Not at all & 26 & 10.37 & 10 & 24.40 \\
\hline & & Total & 251 & $100 \%$ & 41 & 100 \\
\hline
\end{tabular}

This table shows that the majority of grade repeaters, $56.97 \%$ strongly rated that they had repeated a grade due to problem of language of instruction. This view also gains support from 51.21\% of teachers' respondents who reported that problem of instructional language as a very strong contribution of students' grade retention in their schools. Similarly, principals interviewed also support the results that problem of instructional language as a very strong contribution to students' grade retention.

One principal said that:

In our school most of the teachers and students faced the problems of Basic English language especially students have difficulty to understand the subject they learn; therefore, this problem lead students to repeat a grade.

Table 4 also depicts that the majority of grade repeaters $(60.55 \%)$ admitted that they were frequently absent from school during the academic year they had repeated a grade; $70.73 \%$ of teachers also assured students absenteeism as a common problem in their schools. Therefore, absenteeism was a major cause of student grade retention. 
As noticed from this table, $45.42 \%$ of grade repeaters respond that lack of guidance and counseling was a major problem for grade retention. And, $60.98 \%$ of teachers also indicated the existence of the problem in their school. In addition to this, principals interviewed also support the results that lack of guidance and counseling was a major problem for grade retention. One principal said that

In this school there is no trained guidance and counselors and yet, the guidance and counseling service given by the teachers. However, shyness on the part of students' especially female students to approach their male teachers and carelessness of some teachers to provide advice for students are among the reasons for low provision of guidance service in the school. So, teachers did not disguise their failure in providing proper guidance and encouragement for their students.

As shown in Table 4, 29.88\% of grade repeaters and 4.87\% of teachers reported that teachers' verbal proficiency highly contributed students' grade retention. In addition to this, $74 \%$ of grade repeaters and $46.34 \%$ of teachers' respondents reported that teachers' verbal proficiency as averagely contributed to students' grade retention. Similarly, under the inschool related factor principals interviewed also support the results that problem of teachers verbal proficiency contributed to students' grade retention. One of the interviewed principal said that

As you know teachers quality is one of the determinants of students' achievement and yet, in our school most of the teachers lack proper verbal proficiency and proper use of the instructional language.

This table also shows that only $28.69 \%$ of grade repeaters and $9.75 \%$ of teachers reported that large class size averagely contributed for students' grade retention. And, the majority of grade repeaters, $67.33 \%$ reported that teachers were not frequently absent from school during the academic year when they had retained a grade and also $75.60 \%$ of teachers assured teachers' absenteeism was not a common problem in their school. Therefore, the finding clearly shows that teachers frequently absent from school contributed very little for students' grade retention.

In sum, the problem of instructional language and the students frequently absents were the root factor for the students' grade retention in the study area, and teachers verbal proficiency and class size was averagely contributed to students' grade retention. But, teachers frequently absents were less likely to the problem.

4.2.2 Out-of-school factors

Table 5. Out-of-school factors

\begin{tabular}{|c|c|c|c|c|c|c|}
\hline \multirow[t]{3}{*}{ No. } & \multirow[t]{3}{*}{ Out-of-school factors } & \multirow[t]{3}{*}{ Level } & \multicolumn{4}{|c|}{ Respondents } \\
\hline & & & \multicolumn{2}{|c|}{ Grade repeaters } & \multicolumn{2}{|c|}{ Teachers } \\
\hline & & & $\mathrm{F}$ & $\%$ & $\mathrm{~F}$ & $\%$ \\
\hline \multirow[t]{5}{*}{1} & \multirow[t]{5}{*}{ Parents' education } & High & 193 & 76.90 & 24 & 58.53 \\
\hline & & Average & 34 & 13.54 & 17 & 41.47 \\
\hline & & Little & 16 & 6.37 & - & - \\
\hline & & Not at all & 8 & 3.19 & - & - \\
\hline & & Total & 251 & 100 & 41 & 100 \\
\hline \multirow[t]{5}{*}{2} & \multirow{5}{*}{$\begin{array}{l}\text { Parents' education influencing } \\
\text { students' retention }\end{array}$} & Mothers' education & 38 & 15.13 & 7 & 1.34 \\
\hline & & Fathers' education & 35 & 15.39 & 2 & 0.8 \\
\hline & & Both have equal influence & 178 & 70.93 & 32 & 97.86 \\
\hline & & Total & 251 & 100 & 41 & 100 \\
\hline & & High & 118 & 47.01 & 25 & 60.97 \\
\hline \multirow[t]{4}{*}{3} & \multirow[t]{4}{*}{ Helping parents at home } & Average & 73 & 29.08 & 10 & 24.39 \\
\hline & & Little & 42 & 17.73 & 6 & 14.64 \\
\hline & & Not at all & 18 & $6-18$ & - & - \\
\hline & & Total & 251 & 100 & 41 & 100 \\
\hline \multirow[t]{3}{*}{4} & \multirow{3}{*}{$\begin{array}{l}\text { Parents' encourage on } \\
\text { children's education }\end{array}$} & Yes & 96 & 38.24 & 8 & 80.48 \\
\hline & & No & 155 & 61.76 & 33 & 80.48 \\
\hline & & Total & 251 & 100 & 41 & 100 \\
\hline
\end{tabular}


As can be seen in Table 5, 76.90\% of grade repeaters indicate parents' illiteracy or low level of education as strong factor for their grade repetition. This was also supported by $58.53 \%$ of teacher respondents. Besides that, the majority of grade repeaters $(70.93 \%)$ and teachers $(97.86 \%)$ say that both fathers and mother's education equally affect students' grade retention.

As can be observed from the above, $47.01 \%$ of grade repeaters cited their engagement in household activities as strongly related to their grade retention. A large proportion of teachers $60.77 \%$ also reported that helping parents after school hours affect students study time at home. The information obtained from principal interview also suggested that:

Grade repeaters are much involved in helping the family outside school hours for they have little time to study at home and this is an important reason for students not to perform better.

The above table also reveals that the large proportion of grade repeaters $(61.76 \%)$ reported lack of support or encouragement from parents as a reason for their grade retention. The majority of teachers' respondents (80.48\%) affirmed that parents do not encourage their children's educations in their locality. In addition, principals in the interview generalized that lack of parent support as one of the major reason for students' grade retention.

Table 6. The impact of out-of-school related factor in aggravating grade retention by Gender

\begin{tabular}{|c|c|c|c|c|c|c|c|}
\hline Factors & Sex & 1 & 2 & 3 & 4 & 5 & Mean \\
\hline \multirow{2}{*}{$\begin{array}{l}\text { Parent (pupils) health } \\
\text { problem }\end{array}$} & $\mathrm{M}$ & 6.9 & 13.7 & 26.5 & 29.4 & 23.5 & 3.529 \\
\hline & $\mathrm{F}$ & 8.0 & 9.4 & 26.8 & 28.1 & 27.5 & 3.489 \\
\hline \multirow{2}{*}{$\begin{array}{l}\text { Lack of parent } \\
\text { support }\end{array}$} & M & 4.9 & 16.7 & 44.1 & 23.5 & 10.8 & 3.176 \\
\hline & $\mathrm{F}$ & 7.4 & 15.4 & 32.2 & 26.8 & 18.1 & 3.496 \\
\hline \multirow{2}{*}{$\begin{array}{l}\text { Parents low level of } \\
\text { education }\end{array}$} & M & 27.4 & 29.4 & 27.5 & 12.4 & 2.9 & 2.343 \\
\hline & $\mathrm{F}$ & 25.5 & 22.1 & 32.9 & 14.8 & 4.7 & 2.744 \\
\hline \multirow{2}{*}{$\begin{array}{l}\text { Students lack of time } \\
\text { to study }\end{array}$} & M & 23.5 & 28.4 & 33.3 & 13.8 & 0.98 & 2.352 \\
\hline & $\mathrm{F}$ & 26.8 & 26.1 & 28.8 & 12.8 & 5.4 & 1.698 \\
\hline \multirow{2}{*}{$\begin{array}{l}\text { Low level of family } \\
\text { income }\end{array}$} & M & 2.9 & 6.9 & 33.3 & 38.2 & 18.6 & 3.588 \\
\hline & $\mathrm{F}$ & 4.7 & 3.4 & 26.1 & 34.9 & 30.6 & 3.825 \\
\hline \multirow{2}{*}{$\begin{array}{l}\text { Disintegration or } \\
\text { Break down of family }\end{array}$} & M & 49.0 & 24.5 & 16.7 & 5.9 & 3.9 & 1.862 \\
\hline & $\mathrm{F}$ & 40.2 & 30.9 & 22.1 & 5.4 & 1.4 & 2.046 \\
\hline \multirow[t]{2}{*}{ Residence of students } & M & 43.1 & 26.5 & 24.5 & 4.9 & 0.98 & 1.862 \\
\hline & $\mathrm{F}$ & 42.2 & 20.8 & 24.8 & 6.1 & 5.4 & 2.154 \\
\hline \multirow[t]{2}{*}{ Marriage } & M & 43.1 & 16.7 & 20.5 & 4.9 & 2.9 & 1.765 \\
\hline & $\mathrm{F}$ & 57 & 14.1 & 18.1 & 6.7 & 4.1 & 1.859 \\
\hline \multirow[t]{2}{*}{ Child labor } & M & 5.9 & 12.4 & 40.1 & 25.4 & 15.7 & 3.196 \\
\hline & $\mathrm{F}$ & 8.7 & 12.1 & 34.2 & 33.5 & 11.4 & 3.436 \\
\hline \multirow[t]{2}{*}{ Peer pressure } & $\mathrm{M}$ & 33.3 & 20.6 & 39.2 & 5.9 & 0.98 & 2.196 \\
\hline & $\mathrm{F}$ & 38.2 & 24.2 & 29.5 & 6.0 & 2.0 & 2.040 \\
\hline
\end{tabular}

As indicated in Table 6, a considerable number of high school grade nine students (79.4\% of boys and $82.4 \%$ of girls) had repeated from grade due to ill health either themselves or their parents. The cumulative averages (3.529 for boys and 3.489 for girls) indicated that the health problems had seriously affected students' academic achievement of both sexes. In addition to that lack of parental support for their child had $78.4 \%$ of the boys and $86.5 \%$ of girls retained a grade. 90.1 of boys and 91.9 of girls retained a grade because of low level of family income and $81.2 \%$ of boys and $79.1 \%$ of girls retain due to child labor or child excessive involvement of in income generating activities in order to win bread for family or for them. A closely look at the data reveals that disintegration or break down of family affected $26.5 \%$ of boys and $27.5 \%$ of girls' student academic achievement. Moreover, $28.3 \%$ of the boys and $28.9 \%$ of the girls had retained from grade due to marriage, while $46.08 \%$ of the boys and $37.5 \%$ of the girls had retained because of peer pressure.

Therefore, low level of family income was the main out-of- school causes for retention. If the repeaters' family are poor, the students have highly probable to face the exposure of marriage, child labour, lack of time to study, the parents for being illiterate, and even the breakdown of family. 


\begin{tabular}{|c|c|c|c|c|c|c|}
\hline Factor & Gr mean & $\mathrm{R} 1$ & T mean & $\mathrm{R} 2$ & $\mathrm{D}(\mathrm{R} 1-\mathrm{R} 2)$ & $\mathrm{D}^{2}$ \\
\hline Poor quality teaching & 3.505 & 3 & 2.682 & 5 & -2 & 4 \\
\hline Teachers lack of interest to teach & 2.609 & 6 & 1.682 & 9 & -3 & 9 \\
\hline Students lack of interest to teach & 1.936 & 8 & 2.926 & 4 & 4 & 16 \\
\hline Difficulty of language of instruction & 3.725 & 1 & 3.585 & 3 & -2 & 4 \\
\hline Lack of guidance and counseling service for students & 2.629 & 5 & 3.609 & 2 & 3 & 9 \\
\hline Lack of learning materials and facilities & 1.952 & 7 & 1.487 & 10 & -3 & 9 \\
\hline Frequent absenteeism to students & 2.812 & 4 & 2.463 & 6 & -2 & 4 \\
\hline Students failure to study & 3.517 & 2 & 3.878 & 1 & 1 & 1 \\
\hline Large class size & 1.916 & 9 & 1.780 & 7 & 2 & 4 \\
\hline In appropriate examination & 1.848 & 10 & 1.585 & 8 & 2 & 4 \\
\hline
\end{tabular}

Gr: Grade repeaters, R1: Ranks of grade repeaters, T: Teacher, R2: Ranks of teachers, D: Difference b/n paired ranks, $\mathrm{D}^{2}$ : Sum of the squared difference $\mathrm{b} / \mathrm{n}$ rank

In this study, causal factors with the values of the highest mean ranking were those reasons highly rated by grade repeaters and teachers as a major cause for students' grade retention, as opposed to items with values of lowest mean rankings which were taken as the least preferred factors. As the above table indicated that difficulty of language of instruction, students failure to study hard, poor quality of teaching, frequent absenteeism of students, lack of guidance and counseling service for students' were highly ranked factors for students' grade retention.

To measure the degree of agreement between the teachers and students ranking orders of in-school related factors, the Spearman rank order correlation coefficient (rs) was computed. The result revealed a moderately positive but insignificant correlation $(\mathrm{rs}=0.62, \mathrm{p}>.05)$ which implies the selected in-school related factors are insignificantly related to students' grade retention as rated by the respondents.

Table 8. Out-of-school related factors as ranked by grade repeaters and teachers as a cause for students' grade retention.

\begin{tabular}{llllllc}
\hline Factors & Gr mean & R1 & T mean & R2 & D (R1-R2) & $\mathrm{D}^{2}$ \\
\hline Parents (pupils) health problem & 3.505 & 2 & 3.317 & 2 & - & - \\
Lack of parent support & 3.366 & 3 & 3.0 & 4 & -1 & 1 \\
Parents low level of education & 2.581 & 5 & 2.609 & 6 & -1 & 1 \\
Students lack of time to study & 1.964 & 8 & 2.414 & 8 & - & - \\
Low level of family income & 3.729 & 1 & 3.829 & 1 & - & - \\
Disintegration or break down of family & 1.972 & 9 & 1.780 & 9 & - & - \\
Residence of students & 2.047 & 7 & 2.707 & 5 & 2 & 4 \\
Marriage & 1.820 & 10 & 1.731 & 10 & - & - \\
Child labor & 3.338 & 4 & 3.097 & 3 & 1 & -1 \\
Peer pressure & 2.103 & 6 & 2.439 & 7 & -1
\end{tabular}

Gr: Grade repeaters, R1: Ranks of grade repeaters, T: Teacher, R2: Ranks of teachers, D: Difference b/n paired ranks, $\mathrm{D}^{2}$ : Sum of the squared difference $\mathrm{b} / \mathrm{n}$ rank

As can be observed from Table 8, low level of family income, parent (pupils) health problem, lack of parent support and child labor was as the most important factors for their grade retention among out-of-school variables listed in Table 8.

This is also supported by their teachers who rated the variables as a major factor for students' grade retention. This may go with the observed fact of students faced economic problem. This is to say that parental inability to afford educational expense for the children and excessive involvement of children in domestic work as well as in income generating tasks are leads to students' grade retention. Similarly, principals interviewed also the economic factors are the major causes for students grade retention.

One principal said that:

Of course, there are a number of out-of-school factors that lead to students' grade retention, but the major one is child excessive involvement of the family work you know most of the grade repeater comes from the poor 
family they are highly participated in the family work. Because of this, students lack time to study hard that lead students perform low level of achievement.

The result of Spearman rank order correlation coefficient (rs) revealed a very highly positive and significant correlation $(\mathrm{rs}=0.952 \mathrm{p}<.05)$, which implies the selected out-of-school related factors are significantly related to students' grade retention as rated by the respondents.

An attempt was made to look in to the combine effects of those factors by grouping them in to two major categories (inschool related and out-of-school related factors). In this case, the t-test, rank-order correlation and percentages have been computed. When the t-test was applied to check whether or not there was a significant difference between the means of the two populations (teachers and grade repeaters) with respect to the cumulative effects of the in-school related and the out-of-school relate factors the result for in-school related factors, t-critical value is 2.306 (with 8 degree of freedom and 0.05 two tailed level of significance) greater than t-obtained (calculated) value 2.235. This shows the significance of the differences between the opinions of the two groups of respondents. On the other hand, the result for out-of-school related factors, t-critical value is 2.306 (with 8 degree of freedom and 0.05 two tailed level of significance less than t-obtained (calculated) value (8.796). This shows the insignificance of the differences between the opinion of the two groups of $\mathrm{T}$ and $\mathrm{Gr}$ respondents.

Table 9. Students' rank-order correlation for out-of-school related factor by Gender

\begin{tabular}{lllllcc}
\hline Factors & $\begin{array}{l}\text { Males } \\
\text { mean }\end{array}$ & $\mathrm{R}_{1}$ & $\begin{array}{l}\text { Females } \\
\text { mean }\end{array}$ & $\mathrm{R}_{2}$ & $\begin{array}{c}\mathrm{D}^{2} \\
(\mathrm{R} 1-\mathrm{R} 2)\end{array}$ & $\mathrm{D}^{2}$ \\
\hline parental (pupils) health problem & 3.529 & 2 & 3.489 & 3 & -1 & 1 \\
Lack of parent support & 3.176 & 4 & 3.496 & 2 & 2 & 4 \\
Parents low level of education & 2.343 & 6 & 2.744 & 5 & 1 & 1 \\
Students lack of time to study & 2.352 & 5 & 1.698 & 10 & -5 & 25 \\
Low level of family income & 3.588 & 1 & 3.825 & 1 & - & - \\
Disintegration or break down of family & 1.862 & 9 & 2.046 & 7 & 2 & 4 \\
Residence of students & 1.892 & 8 & 2.156 & 6 & 2 & 4 \\
Marriage & 1.765 & 10 & 1.859 & 9 & 1 & 1 \\
Child labor & 3.196 & 3 & 3.436 & 4 & -1 & -1 \\
Peers pressure & 2.196 & 7 & 2.040 & 8 & -1 \\
\hline
\end{tabular}

R1: Rank of male; R2: Rank of female; D: Difference b/n paired ranks; $\mathrm{D}^{2}$ : Sum of the squared difference b/n rank

Further, the study has attempted to compare the impact of the out-of-school and in-school related factors by gender with respect to the ranking of the mean scores (See Table 5). As a result, among the ten out-of-school related factors, the first four main factor with mean scores 3.0 and more) for aggravating grade retention for the males include low level of family income, parental (pupils) health problem, child labor and lack of parental support in that order of ranking (from 1-4). In the case of females, they are raised to three which include low level of family income, lack of parental support and parental (pupil) health problem in that order of rankling (from 1-3).

To measure the degree of agreement between the ranking orders of out-of-school related factors the Spearman rank order correlation coefficient (rs) and t-test was computed. This result of the rank order correlation for in-school related factors listed in Table 7 despite the observed difference on some items shows positive correlation ( $\mathrm{rs}=0.746$ at 0.05 , two tailed) and the t- computed value 3.168 at 0.05 and $8 \mathrm{df}$, this shows that both male and female grade repeaters were equally influenced by out-of-school related factors considered in this study.

Among the ten in-school related factors, the first two main factor (with mean scores 3.0 or more) for aggravating students' grade retention for the males include difficulty of instructional language and students failure to study hard in that order of ranking (from 1-2). In the case of girls, they are raised to three which include low quality of teaching, difficulty of instructional language and students failure to study hard in that order of ranking (from 1-3).

The established correlation coefficients for the two set of mean scores (male and female grade repeaters) are found to be 0.746 for the out-of-school factor and 0.891 for the in-school related factor. These values are also found to be statistically significant beyond 0.05 two tailed level of significances. This implies that the selected reasons exhibited a strong relationship for the selection by male and female grade repeaters. In other words, both groups of factors influenced both groups of grade repeaters in more or less similar degree. What is more, when the cumulative percentage of influence for each of the factors is computed, out-of-school related factors accounted for $55.2 \%$ of the total influence while the in-school related factors accounted for $50.2 \%$ of the total influence. 


\begin{tabular}{lllllll}
\hline \multicolumn{2}{l}{ Table 10. Students' rank-order correlation for in-school related factors by gender } \\
\hline Factors & Male mean & R1 & Female mean & R2 & D (R1-R2) & D $^{2}$ \\
\hline Low quality teaching & 2.980 & 3 & 3.838 & 1 & -2 & 4 \\
Teachers' lack of interest to teach & 2.460 & 6 & 2.711 & 4 & -2 & 4 \\
Students' lack of interest to learn & 1.921 & 8 & 1.899 & 10 & -2 & 1 \\
Difficulty of language of instruction & 3.647 & 1 & 3.731 & 2 & -1 & 1 \\
Lack of guidance and counseling service for students & 2.588 & 5 & 2.563 & 6 & -1 & 1 \\
Lack of learning materials and facilities & 1.931 & 7 & 2.00 & 7 & - & - \\
Frequent absenteeism of students & 2.696 & 4 & 2.651 & 5 & -1 & 1 \\
Students' failure to study hard & 3.568 & 2 & 3.181 & 3 & -1 & 1 \\
Large class size & 1.882 & 9 & 1.959 & 8 & 1 & 1 \\
Problem of test & 1.671 & 10 & 1.845 & 9 & 1 & 1 \\
\hline
\end{tabular}

Maglad (1994) also asserted that findings that one factors that increased the retention rate among students in secondary school in that most of them have difficult to comprehend the subject due to language problem and they cannot follow their courses properly. Besides that, Jimmerson and Kaufman (2003) put that language is a large part of any professional task. They added the success of secondary school mainly depends upon the level of achievement in language.

\section{Conclusion}

Based on the analysis of the finding, it was found that grade retention was caused by multitude of factors which emanated from both what students have encountered in-school and out-of-school environment. In other words, the majority of grade repeaters and teacher respondents' grade retention in grade nine Dabat district general secondary schools were the functions of both selected in-school related and out-of-school related causes.

This research depicts that $70.9 \%$ grade repeaters' father and $88.84 \%$ of their mothers' educational level were illiterate. Indeed, both mothers and fathers education were said to have equal influences on students' grade retention. A number of studies have found the educational back ground of parents is an important determinant factor of students' academic progress (Caron and Chau, 1996; Debela, 1980). Parents who are themselves educated may have a more enlightened attitude about children education or provide a more stimulating environment for education of their children than uneducated one. Researchers like Wanna and Tsion (1994) in the case of Ethiopia schools, found that grade retention for students is higher for those whose parents are illiterate than literate. A person offered for such differences is that literate parents have better awareness of chance waiting educated children than illiterate parents. Fine (1987) also revealed that the educational background of parents highly contributed for the success or failure of students (i.e, poor educational background of parents adversely affect students' academic performance).

Among the in-school related factors included in the study, difficulty of language of instruction, students' failure to study hard, lack of guidance and counseling service for students, poor quality of teaching, and frequent absenteeism were identified as a major causative factor for students' grade retention in grade nine in Dabat district general secondary schools. Tilaye (1999) states that one factors that increased the retention rate i in Ethiopia among students in secondary school in that most of them have difficult to comprehend the subject due to language problem and they cannot follow their courses properly, they have difficulty of understanding and appropriate manipulation of English language. Hargewoin and Yusuf (1994) and Ballantine (1993) seem to assert that guidance and counseling services in secondary schools are more important for adolescence because of absenteeism, dropout, repetition inferiority complex, late coming to school, etc. And, Haddad (1979) reveals that frequent absenteeism from school (14 days to 2 months) is behavior highly associated with repetition of classes and dropout

The finding of this study also reveals that the incidences of the problem which emanated either from the in-school or out-of-school systems were found to be relatively high for females than for males' grade repeaters. Several research reports such as Elsemon (1997) and UNESCO (1993) indicated that the tendency to repeat grades are higher among girls than boys because of girls' responsibilities at home and the gender division of labor in the house hold economy. Elsemon (1997) report on ten African countries that more than one female student out of three were actually repeating in general secondary school.

$45.42 \%$ of grade repeaters respond that lack of guidance and counseling was a major problem for grade retention. And, $60.98 \%$ of teachers also indicate the existence of the problem in their school. The current result seems to support what documented by UNESCO (1987) that lack of properly organized guidance and counseling service relate to "poor progress" of students particularly in secondary schools.

$29.55 \%$ of grade repeaters and $4.87 \%$ of teachers reported that teachers' verbal proficiency highly contributed students' grade retention. In addition to this, $63.74 \%$ of grade repeaters and $46.34 \%$ of teachers respondents reported that teachers 
verbal proficiency as averagely contribute to students grade retention. In this way, the finding supports with what was reported by Good and Brophy (1992) and Fuller (1986) were that the verbal proficiency of teacher are determining students' academic achievement.

The highest mean score of male grade repeaters such as 3.588, and female repeaters such as 3.825 indicated that low level of family income had had the highest probability to face the challenge of retention in out-of-school causes, and 3.51 highest mean score was registered to be poor quality of teaching had higher probability to encounter the challenge of retention than other in-school factors. Brimer and Pauli (1975:7) stated that even if parents of the low Socio Economic Status provide poor achievement for their children, their children could have good academic performance due to their brilliant activities in learning processes, and through his SES parents provide good environment themselves grow up in their children on the average could have low academic performance due to less effort they devoted for schooling activities.

\section{References}

Anderson, R. (1969). "Pupils Progress. In Ebel, R(Ed)." Encyclopedia of Educational Research, $4^{\text {th }}$ ed. Toron to Ma Millian

Anderson, G. E., Jimerson, S. R., and Whipple, A. D. (2005). Student Ratings of Stressful Experiences at Home and School: Loss of a Parent and Grade Retention as Superlative Stressors. Journal of Applied School Psychology, 21, 1-20.

Arends, R. I. (1994). Learning to Teach. New York Mc Grawhill companies Inc.

Assefa, B. (1991). Female Participation and Performance in Rural Primary Schools in Ethiopia. Addis Ababa UNICEF/SIDA.

Bandura, A. and Walters, R. (1963). Social Learning and Personality Development. New York: Holt, Rinehart and Winston.

Bandura, A. (1986). Social Foundations of Thought and Action. Englewood Cliffs, NJ: Prentice-Hall.

Bandura, A. (1997). Self-efficacy: The Exercise of Control. New York: W.H. Freeman.

Bernard, H. R. (2000). Social Research Methods. International Educational and Professional Publisher. Sage Publishing, Inc.

Blair, C. (2002). School Readiness: Integrating Cognition and Emotion in a Neurobiological Conceptualization of Children's Functioning at School Entry. American Psychologist, 57, 111-127.

Brimer M.A. and Pauli, L. (1971). Wastage in Education a World Problems. Paris. UNESCO.

Brodbelt, S. (1987). Absenteeism: Critical Problem in Learning. Journal of Disabilities. 19(8).

Brophy, J. (1983). Research on the Self-Fulfilling Prophecy and Teacher Expectations. Journal of Educational Psychology, 75, 631-661

Brown, G. (1991). Education in the Developing World: Conflict and Crisis. London LONGMAN.

Bustillo, I. (1993). Latin America and the Caribbean in Enn King and M.A. A Hill Women's Education in Developing Countries, Barriers, Benefits and Policies. Baltmore the Jhon Hopkins University press.

Carron G. and Chan, T.G. (1996). The Quality of Primary Schools in Different Development Contexts. Paris UNESCO.

Cole. 1997. Promoting Equality in Primary Schools: Lendon Daverlill and Saaran Jeha.

Cooksey, B. (1992). Education and Sexual Inequalities in Cameroon. Journal of Modern African Students. 20, $167-177$.

Dereje, T. and Dresse, M. (1997). Violence in schools: A Study of Some Schools in Addis Ababa. Global Issue and Intervention. Press UNESCO.

Eisemon T.O. (1997). Reducing Repetition: Issue and Strategies. Paris UNESCO.

Fasil R. K. (1990). Implementing Education Policies in Ethiopia. The World Bank, Washington, D.C. Library of Congress Cataloging-in-Publication Data

Festinger, L. A. (1954). A Theory of Social Comparison Processes. Human Relations, 7, 117-140.

Fine, M. (1987). Why Urban Adolescents Drop in to and Out of Public High School? In G.N, Natriello (Ed). School Dropouts, Patterns and Policies (pp.89-105). New York Teachers College.

Fuller, B. (1986). Raising School Quality in Developing Countries. What investment boost learning? Washington D.C World Bank.

Fuller, B. (1987). What Factors Raise Achieving Third World. Review of Educational Research, 57 (3).

Garman, C.G, and Brown, W.K. (1989). Truancy, Chronic Absenteeism and Dropping out. New York: William Gladden foundation. 
Genet, Z. (1998). Women in Education: A Study of the Academic Performance and Participation of Female Students in the High Schools of Addis Ababa Region. FALMBEAU, 6(1).

Good, J., and Brophy, J.E. (1986). School Effects. In M.C. Wittrock. Handbook of Research on Teaching (3 ${ }^{\text {rd }}$ ed). New York: Maemylon.

Good, T. and Brophy, J.E. (1992). Educational Psychology. A Realistic Approach (5 ${ }^{\text {th }}$ ed): London. Longman Publishing Company.

Haddad, W.D. (1979). Education and Economic Effects on Promotion and Repetition Practicing. World Bank Staff Working Paper No. 519 Washington D.C World Bank.

Hamblin, D. (1983). Guidance: 16-19 Age Group London Brass Bank Well.

Hirschi, T. (1969). Social Control Theory. Sage Publishing, Inc.

Hussen, E. (2000). Is Grade Retention Desirable? Educational Journal. 4(8). 31-43, MOE.

Hyde, K. (1989). Improving Women's Education in Sub Saharan African. A Review of Literature Washington D.C. World Bank Jimerson, S., Egeland, B., Sroufe, L., and Carlson, B. (2000). A Prospective Longitudinal Study of High School Dropouts: Examining Multiple Predictors across Development. Journal of School Psychology, 38, 525-549.

Jimerson, S. R. and Kaufman, A. M. (2003). Reading, Writing, and Retention. A Primer of Grade Retention Research. The Reading Teacher Journal, 56(7), 622-635

Jimerson, S.R. Whipple, A.D and Anderson. G.E. (2002). Grade Retention, Achievement and Mental Health Outcomes. Betheda, MD. National Association of Psychologists.

King, E.M. and Hell, M.A. (1993). Women's Education in Developing Countries: Barriers, Benefits and Policies, Baltimore: The Johns Hopkins University Press.

Levy, M. B. (1971). Determinants of primary school dropouts in developing countries. Comparative Education Review, 15(1), 44-58.

Lopez, J., Maoulidi, M. (2009). The Cost of Grade Retention. Forthcoming: Review of Economics and Statistics. Discussion Paper for Educational Needs Assessment for Mekelle City, Ethiopia.

Maglad, N.E.A. (1994). School Supply, Family Background and Gender Specific School Enrollment and Attainment in Sudan. East Africa Social Science Research Review, 10(2)

Maxwell, W.H. 1904. Sixth Annual Report of the Super Intendment of School. New York City Board of Education.

Mayer, D. P., Mullens, J. E., \& Moore, M. T. (2001). Monitoring School Quality: An Indicators Report. Education Statistics Quarterly, 3(1), 38-44. McCoy, A. R., and Reynolds, A. J. (1999). Grade Retention and School Performance: An Extended Investigation. Journal of School Psychology, 37, 273-298.Merga, F. (1999). Factors that Contribute to Female Students Grade Repetition in Secondary Schools of Jimma Zone.

Miske, S. J., and Dowd, A. J. (1998). Teaching and learning in Mangochi classrooms: Combining quantitative and qualitative information to study twelve primary schools in Malawi. Creative Associates International. Washington D.C

MOE (1994). Education and Training Policy. Addis Ababa.

MOE (1998). What Factor Shape Girls School Performance Addis Ababa. (Unpublished Research Report).

MOE (1998/99). Indicators of the Ethiopian Education System. Addis Ababa

Mulualem, A. (2011). The Impact of Student Dropout up on the Attainment of UPE Program in West Gojjam. Unpublished Master Thesis, Bahirdar University Library.

Nailing, X. and Sheila, N. K. (2009). Retaining Students in Grade. A Literature Review of the Effects of Retention on Students' Academic and Nonacademic Outcomes. Rand Corporation.

National Association of School Psychologists. (1989). Grade Retention and Social Promotion: Position Statement.

Owings, W.A and Magliarols. (1998). Grade Retention: A History of Failure. Educational Leadership, 56, 86-88.

Pagani, L., Tremblay, R. E., Vitaro, F., Boulerice, B., and McDuff, P. (2001). Effects of Grade Retention on Academic Performance and Behavioral Development. Development and Psychopathology, 13, 297-315.

Pianta, R. C., Tietbohl, P. J., and Bennett, E. M. (1997). Differences in Social Adjustment and Classroom Behavior between Children Retained in Kindergarten and Groups of Age and Grade Matched Peers. Early Education and Development, 8, 137-152.

Potter, L. (1999). Examining the Negative Effects of Retention in our School. Educational Journal, 117(2), $268-271$.

Reynolds, A. J. (1992). Grade Retention and School Adjustment: An Explanatory Analysis. Education Environment and Policy Analysis, 14(2), 101-121.

Robinson D.N. (2000). Teaching: Trends in research In N.J. Smelser, and P.B., Baltes. (Eds). International Encyclopedia of Social and Behavioral Sciences. UK: Cambridge university press. 23, 15483-15487. 
Roderic, M. (1994). Grade Retention and School Dropout: Investigating the association. American Educational Journal, 3 (479-759).

Rose, P., Yoseph, G., Berihun, A., and Nuresu, T. (1997). Gender and Primary Schooling in Ethiopia. Brighten IDS.

Schiefeldbein. E., and Farrell, J. (1973). Factors influencing academic performance among Chilean primary students. Santiago: Centro de investigaciones y Desarrollo de la Education. Century World Bank Discussion on Paper No 257, Washington D.C. World Bank.

Setencich, J. 1994. The Impact of Early Grade Retention on the Academic Achievement and Self-Esteem of Seventh and Eighth Grade Students (ERIC Document Reproduction Service No. ED393026 p.1-11).

Setu, A. (2002). Internal Efficiency of Primary Schools in the Amhara National Regional State (Unpublished thesis). AAU.

Shepard, L., and Smith, M. L. (1990). Synthesis of Research on Grade Retention. Educational Leadership, 47(8), 8488Thomas, A.H. (1975). Alternatives to Retention." If Failing Doesn't Work, What Does? Oregon School Study Council, 35(6), 1 - 41. (ERK Document Reproduction Service No. ED 343, 209)

Thomas, K. (1990). Gender and Subject in Higher Education. Great Britain: The Society of Research into Higher Education and Open University press.

Tilaye, K. (1997). Gender-Specific Investigation into the Problem of High School Dropout in the Amhara Region. Unpublished Master's Thesis, AAU.

Tilaye, K. (1999). The Problem of Secondary Schools in East Gojjam. The Ethiopian Journal of Education, XXX(1).

Tomchin, E. M., and Impara, J. C. (1992). Untraveling Teachers' Beliefs about Grade Retention. American Educational Research Journal, 29, 199-223.

UNESCO. (1980). Wastage $n$ Primary and Secondary Education: A Statistical Study of Trends and Patterns in Repetition and Dropout, (SRE, 3) Paris Division of Statistics on Education Office of Statistic, UNESCO.

UNESCO (1984). Wastage in Primary Education 1970, 1980. Prospects, 14(3).

UNESCO (1988). Wasted Opportunities. When School Fail Repetitions and Dropout in Primary School Paris. UNESCO.

UNESCO (1995). Differentiated Types of Community Involvement that Help Minimizing Educational Wastage.

UNESCO (1998). World Education Report 1995, Paris. UNESCO

UNESCO (2002). The World Education Form, Paris. UNESCO

UNESCO (2014). Global Partnership for Girls' and Women's Education in Ethiopia-One Year On

UNICEF (1988). Children and Women in Ethiopia. Paris WK.

Wanna, L. and Tsion, D. (1994). Educational wastage: The case of female students in selected primary and secondary school of Ethiopia. Unpublished Research Report, AAU, CCRTWLD

Weiner, G. (1978). Education and the sex discrimination act. Educational Research, 20(3), 163-173.

Widdowson, H.G. (1978). Teaching Language as Communication. London, Oxford University Press.

Wilcox, R.T. 2000. Effective Teaching in Ethiopia. Addis Ababa University Press.

World Bank. (1998). Education in Sub-Saharan Africa: Policies for Adjustment, Revitalization and Expansion. Washington, DC World Bank.

World Bank. (2002). Education in Ethiopia: Strengthening the Foundation of Sustainable Progress.

World Bank. (2014). Region: Sub Saharan Africa Income Group: Low Income. Updated National Educational Profile of Ethiopia.

Worku, Y. (1995). Primary school female participation and performance in Cheha district. Ministry of Education. 